\title{
突風による飛散物の構造物に対する影響評価 \\ Assessment of Flying-debris-impact to Structure Caused by Gust Wind
}

\author{
丸山 敬*
}

Takashi MARUYAMA

\section{1.はじめに}

竜巻やダウンバースト，あるいは，台風などに伴う突 風による建物被害を見ると, 風圧力による被害だけでな く, 強風によって発生した飛散物による被害が多くみら れる。したがって，それらの被害を防止あるいは低減す るためには, 飛散物による被害の発生メカニズムを明ら かにし，対策を立てる必要がある。ここでは，突風によ る飛散物の飛着性性状, 衝突による衝撃力の大きさ, 衝突 によって生じる破壊の程度と耐衝撃性能の評価方法に ついて,これまでに得られている学術的見地をもとに概 観する。

\section{2. 飛散物の飛翔性状と衝突速度}

飛散物の飛翔特性と衝撃力を知るためには，突 風中の飛散物の飛翔運動を予測し, 建物に衝突寸 る際の速度を明らかにする必要がある。飛散物の 飛翔運動に影響を与える要因としては突風の気 流性状, 飛散物の空力特性, および，飛散開始時 の条件が考えられる。衝撃力については, 飛散物 の持つ運動量や運動エネルギー, さらには, 飛散 物の形状や硬さや密度などの物性, 角度, 衝突す る位置などの衝突性状, 衝突する相手側の特性な どによって変化するが, ここでは運動量や運動工 ネルギーとしての衝撃力の評価, 寸なわち, 飛散 物の衝突速度に関して述べる。それ以外の影響に ついては，次節に含めて述べることにする。

\section{1 突風の気流性状}

ここでは突風の気流性状に関して，飛散物の飛翔運動 を解析する際に考慮すべき点を挙げる。

（1）風速分布 : 突風の原因となる竜巻やダウンバース 卜は水平方向だけでなく鉛直方向も含めた 3 次元的な風 速分布をもっている。したがって，風速の時空間分布を 明らかにし，評価する必要がある。

（2）時空間分解能 : 突風内の風速分布や荷重の継続時 間は数秒程度であるので，それ以下の時間分解能と，そ れに対応して飛散物の運動を再現するための時空間分解 能が必要となる。

（3）継続時間・滞留時間 : 突風の空間的な大きさと突 風域の移動速度から算定される。竜巻の場合は渦径と移 動速度から算定できる。その他の場合はおおよそ数秒程 度を想定できる。

（4）静圧分布（気圧低下）: 突風中の静圧分布のスケー ルに比へて飛散物の代表長さは, 通常十分小さいと考え られるので, 飛散物の運動を解析する際に静圧の空間分 布による飛散物表面の圧力変化を考慮する必要はないと 考えられる。一方, 飛散物の発生原因となる構造物の破 壊には突風中の静圧分布の影響は大きいので考慮する必 要がある。竜巻の場合には，例えば，ランキン渦に代表 されるようなモデル渦の風速分布に対応した静圧分布を 仮定することができる。あるいは，風速と圧力分布を同 時に解く数值解析の結果を用いることができる。

（5）最大風速半径, 移動速度 : 竜巻に関して最大風速 
半径は渦の大きさを表す量であり，日本ではおおよそ数 十メートル程度を想定する。奥田ら ${ }^{1)}$ は, 2012 年に茨城 県つくば市で発生した竜巻について，その被害分布と竜 巻の画像処理結果から竜巻の半径を約 $35 \mathrm{~m}$ と推定してい る。また, 竜巻の移動速度はおおよそ秒速十数メートル 程度を想定する。

（6）スワール比：竜巻に関して渦の性状を決めるパラ メータで, 実物ではスワール比が $0.05 \sim 2$ 程度である。ス ワール比が大きくなると, 層流渦から乱流渦, 副次渦を もつ複合渦へと変化することが知られている。なお，渦 の大きさや性質はスワール比に依存するが，レイノルズ 数にはほとんど影響されないことが明らかになっている。

その他, 周辺の地形, 地表面粗度, 周辺の建物や樹木 など遮蔽効果を及ぼす地物は突風の気流性状に影響を与 える。しかし, それらの効果を一般化することは難しく, 風洞実験や数值流体計算で適宜再現実験を実施する必要 がある。

\section{2 飛散条件}

飛散物が飛散を開始する状況に関しては多くの条件が 考えられ, 実際の飛散ではそれらが複雑に関係している。 解析上はこれらをすべて取り上げることは不可能である ため，飛散性状に影響を及ばす条件をよく吟味したうえ で, 必要となる飛散条件を選択し, 解析に用いることに なる。以下に考えられる実際の飛散条件を挙げる。

（1）位置 : 飛散物が飛び始める高さ, 周辺の地形, 建 築物・構造物との相対的な位置関係。さらには, 突風と の相対的な位置関係，例えば竜巻の場合，渦の中心から の相対位置により, 飛散開始時の風速や風向が変化する ため, 飛翔特性が変化する。

（2）姿勢: 飛散開始時の飛散物の姿勢は相対的な風速 を変化させ, 飛散物に加わる空気力が変化するので, 飛 翔特性も変化する。

（3）飛散開始風速: 物体の飛散開始は物体の形状, 重 さ，物体の置かれている位置や固定状態，吹き付ける気 流性状に左右される。Wills ら $^{2)}$ は飛散物の形状を塊状, 板状, 棒状の物体に分け, それらの飛散開始風速を考察 した。それによると, 塊状の物体はその代表径が大きく なるほど, 板状の物体は奥行や幅によらずその代表厚さ が大きくなるほど, 棒状の物体は長さによらずその代表 径が大きくなるほど飛散開始風速は大きくなることを示 している。また, 岡田 ${ }^{3)}$ によると長方形平面を有する 2 階建ての建物模型を用いた風洞実験では, 留め付けられ ていない和形栈瓦は軒高さの平均風速に換算して $30 \mathrm{~m} / \mathrm{s}$ 前後で飛び始めるという結果が得られている。

\section{3 気流中の飛翔運動}

物体が飛散を開始した後の運動については, 実験や数 值計算により研究されている。立川ら ${ }^{4)}$, Tachikawa $^{5)}$ は一様流中で矩形平板に作用する空気力と飛散運動に関 して回転を伴う場合も含めて測定し，計算した物体の軌 跡と実験結果を比較して, 初期風向角が飛散性状に影響 を与えることを見出した。さらに立川 ${ }^{6)}$ は, 飛散の広が り方も検討し, 建物に衝突する飛散物の拡散範囲の推定 法も提案している。Wang $ら^{7)}$ やHolmes $ら^{8,9)}$ は風洞実 験に対応した矩形平板の解析を行っている。また, Noda $ら^{10)}$ は種々の形状の矩形平板に対する 6 分力を実験的に 求め, 飛散性状の解析を行っている。塊状の物体の解析 としては Holmes ${ }^{11)}$, English ら ${ }^{12)}$ が, 棒状の物体の解析 についてはLin ${ }^{13)}$, Richards ら ${ }^{14)}$ が挙げられる。一方, 物体の飛散性状は流れ場の気流性状にも左右され, 森本 ら ${ }^{15)}$ は地面付近の乱流場を想定し球状落下物の及ぼす飛 散距離に及ぼす強風時風速変動の影響を調べている。

回転流中での室内実験による研究例としては, 喜々津 $ら^{16)}$ が矩形状の厚紙を竜巻発生装置の中で飛散させた実 験を行い，飛散物の発生源の位置による飛散物の衝撃リ スクの変化を調ベた。山下ら ${ }^{17)}$ は発泡スチロールビーズ を用いて, 竜巻によって巻き上げられる飛散物の性状を 調べた。さらに, 伊藤ら ${ }^{18)}$ は, 渦直下の水面における水 しぶきの形状や水滴の飛散性状を実験的に観察し, 水滴 は飛び出し時の初速度に依存してほぼ一直線に飛散し, 放物運動として扱うことができ, その飛散距離は渦の接 線風速の二乗に比例することを見出している。一方、宮 城ら ${ }^{19)}$ や野田ら ${ }^{20)}$ は実際の竜巻被害において撮影され たビデオ映像から飛散物の速度が求めており、被害状況 から推定された最大風速程度の速度をもっていることが 判っている ${ }^{21)}$

数值計算による解析例としては, Katafuchi ら $^{22)}$ が一様 流中で回転しながら飛散する 2 次元平板についてラージ エディシミュレーション (LES) により周りの流場を含 めた解析を行っている。また, Kakimpa $ら^{23)}$ は $\mathrm{k}-\varepsilon$ 乱流 モデルを用いた乱れの小さい非定常流れ場において，正 方形平板の回転運動を含めた 3 次元飛散性状を調べてい る。一方, 物体の飛散性状は流れ場の気流性状にも左右 され, 実際の強風場は, 地面付近で乱れているので, 乱 流場における飛散性状を明らかにする必要がある。乱流 場における解析例としては, 田村ら ${ }^{24)}$ が実在都市上空で のLES で再現している。Himoto ら ${ }^{25)}$ は火の粉の飛散に 関する基礎的研究として, 熱プリューム内における正方 形平板の飛散性状をLES により解析している。森本ら ${ }^{26}$ 
は, 数值的に生成した乱流境界層流れを用いて球状物体 の飛散を, 野田ら ${ }^{27)}$ は平板に対する、岡崎ら ${ }^{28)}$ は平板 と瓦に対寸る解析を行っている。

飛散物の飛翔運動を空気力を外力とする運動方程式に よって解析する場合, 並進運動だけを計算する場合と, 回転運動を含めた 6 自由度運動を計算する場合がある。 前者の解析においては, 物体を球体のように空気力が相 対風向角によって変わらないと仮定して計算するのが最 も簡単なモデル化である。6 自由度運動を計算する場合 には, 空気力係数および空力モーメント係数を相対風向 角に対して知る必要があるが，これらは物体を風洞内に 固定して実験的に求められることが多い。また, 物体の 回転に起因するマグナス効果や回転による非定常効果な ども場合によっては考慮する必要があるが，任意形状の 3 次元物体を前提としてマグナス効果や減衰モーメント を考慮することは実際には非常に困難である。さらに, 実際の飛散においては相対的な風速・風向角が動的に変 化するので，上記のように静的な条件で測定されたパラ メータの值が妥当であるかを直接比較するためのデータ が不足しているのが現状である。しかしながら, 乱流境 界層中で多数の平板を飛散させた岡崎ら ${ }^{28)}$ によるモンテ カルロシミュレーションの結果によると, 球体の場合と 比較して飛散範囲や速度分の統計量に大差がないことが 判っている。

竜巻のような渦中の飛散物の運動を数值計算により解 析する場合, 竜巻を模擬する気流として, ランキン渦な どのモデル化された流れ場を用いる場合や, 数值流体計 算によって, 竜巻状の非定常な回転流場を発生させて用 いる方法がとられる。モデル化された流れ場を用いた解 析例としては, Simiu ら ${ }^{29)}$ が高さ方向に一様なランキン 渦を仮定した解析を行い, その結果は米国の原子炉の安 全設計基準 ${ }^{30)}$ に用いられている。実際の竜巻による建物 の強風被害に対しては, 2007 年に北海道で起こった佐呂 間町の竜巻被害について, 河井 ${ }^{31)}$ がランキン渦を仮定し て, 江口ら ${ }^{32}$ 飛散物は竜巻風速場としてフジタモデル ${ }^{33)}$ を用いた解析を行っている。一方, 数值流体計算で竜巻 を 3 次元の非定常乱流場として再現し，その中で物体が どのように飛散するかを解析する方法もとられる。たと えば, Lewellen ら ${ }^{34)}$ は飛散物を細かな粒子の流れと仮定 し, 密度の異なる 2 相流として, また, Maruyama ${ }^{35)}$ はL E S により発生させた非定常な洞状の流れ場を用いて飛

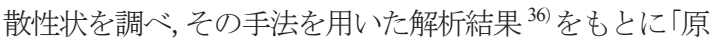

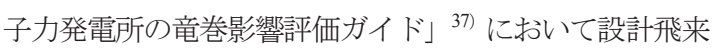
物が示されている。

\section{4 衝突速度}

衝撃力は飛散物の持つ運動量や運動エネルギー，さら には, 飛散物の形状や硬さや密度などの物性, 角度, 衝 突する位置などの衝突性状, 衝突する相手側の特性など によって変化する。Vickery ら ${ }^{38}$ は，ハリケーンによる飛 散物が建物に衝突する際の衝撃度を衝突角および速度を 使ったインパクトファクターで評価し, 衝撃力はインパ クトファクターと物体の運動量の積で評価することを提 案している。一方Wills ら ${ }^{2)}$ は, 飛散物の衝撃による被害 が飛散物の運動エネルギーに比例するとし，飛散物の衝 突速度と物体が飛散し始める風速の関係を調へ，被害の 程度と飛散開始風速の関係を考察している。以下では運 動量や運動エネルギーとしての衝撃力の評価の基本とな る飛散物の速度に関して述べる。

物体の飛散しやすさを表すパラメータは，無次元化さ れた運動方程式中に現れ, 空気密度 $\rho$, 物体の代表面積 $A$, 風速 $V_{0}$, 飛散物の質量 $m$, 重力加速度 $g$ を用いて 物体に作用する空気力と重力の比 $T_{\mathrm{a}}=\rho A V_{0}^{2} /(2 m g)$ とし て定義される Tachikawa 数 ${ }^{39)}$ で表される。このパラメー タ中には空気力係数を含まず，物体の形状の影響を含ん でいないので, 空力パラメータ $C_{\mathrm{D}} A / m\left[\mathrm{~m}^{2} / \mathrm{kg}\right]$ で評価す る場合も多い。ここで $C_{\mathrm{D}}$ は空気力係数である。

建物に被害を及ぼす飛散物は様々であるが，米国の原 子炉の安全設計基準 ${ }^{30)}$ などでは, 代表的な飛散物を, 大 きな運動エネルギーをもつもの（自動車等），貫入による 影響の大きなもの (鉄骨部材等), 開口部を通過しうる程 度に小さく固いもの（砂利等）のように分類している。 これらの飛散性状を実験的に明らかにすることは困難な ことが多く, 通常は被害状況や上に述べたように実験, あるいは，数值シミュレーションによって求めている。 その際, 物体の空力特性を示寸 Tachikawa 数 $T_{\mathrm{a}}$ や空力パ ラメータ $C_{\mathrm{D}} A / m$ の值は飛散性状を左右するので重要と なるが，代表的な飛散物の值として単純な形状の物体が もつ值が用いられていることが多い。しかし，空気力係 数は物体の形状に依存して変化するので, 飛散物の形状 に応じた值，とくに風向風速が動的に変化する場合の空 気力係数の值を明らかにすることはより精度の高い解析 のために必要である。

以下では数值流体計算で竜巻を 3 次元の非定常乱流場 として再現し，その中の物体の飛翔運動を数值計算によ り求めた結果 ${ }^{40)}$ を示す。計算において飛散物の空力特性 は運動方程式中のパラメータ $T_{\mathrm{a}} C_{\mathrm{D}}$ あるいは $C_{\mathrm{D}} A / m$ 表 される。この值について, 竜卷の乱流中では風向や風速 が時空間的に変化するので, 空力特性は相対風向角によ 


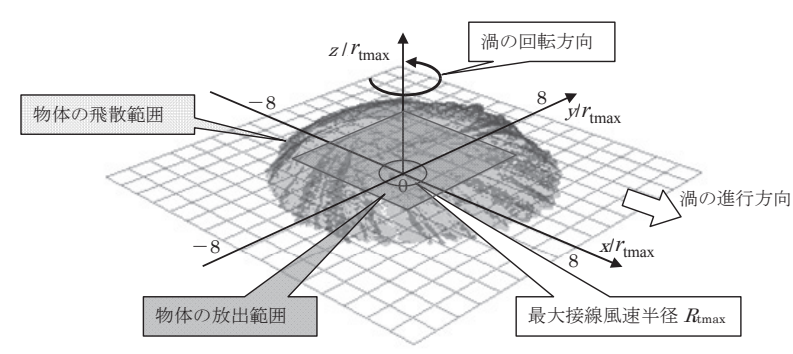

図 1 物体の飛散例（渦に固定された座標系で表示）

らず平均的な值を用いても計算結果の統計量に大きな影 響を与えないと考え，各軸方向の代表的值を各方向の面 積で重み付した平均值として空気力係数を代表させる。 また，風向風速が変化する気流内では，マグナス効果の 影響も小さいと考え, 無視している。飛散物としては, 衝突により風下の建物を破壞して被害を及ぼす可能性の 高い，比較的遠くまで飛ぶ物体（小石や木片）老取り上 げた。これらの空力パラメータ $C_{\mathrm{D}} A / m$ の值の範囲 0.007 $\sim 0.07 \mathrm{~m}^{2} / \mathrm{kg}$ には, 例えば, $1 \times 1 \times 1 \mathrm{~cm}^{3}, 3 \mathrm{~g}$ の小石, $10 \times 10 \times 10 \mathrm{~cm}^{3}, 3 \mathrm{~kg}$ の石, $10 \times 10 \times 10 \mathrm{~cm}^{3}, 0.5 \mathrm{~kg}$ の木片, $0.04 \times 0.09 \times 2 \mathrm{~m}^{3}, 3.6 \mathrm{~kg}$ の木の棒などが含まれ, 最大接線風 速 $U_{\text {tmax }}=80 \mathrm{~m} / \mathrm{s}$ とした場合, $T_{\mathrm{a}} C_{\mathrm{D}}$ の值では 3 から 28 の範 囲に対応している。計算に用いた渦の気流性状は渦が移 動しない場合の計算結果を用いており, 物体の運動を計 算する座標系では投入時の物体の速度は渦の移動速度 （反対方向）とし, 飛散物の対地速度は静止状態の竜巻 の流れ場で求めた物体の飛散速度と渦の移動速度の和と して求めた。得られた結果を以下にまとめる。なお、計 算の詳細は文献 35,40）を参照されたい。

図 1 に物体の飛散例を示寸。渦は上から見て反時計回 りに回転し $x$ 軸方向に移動している。物体はおおむね渦 の回転に沿って飛散する。物体は放出位置において, 物 体を持ち上げるのに十分な鉛直上方の風速成分が存在す ると, いったん上昇した後, 下降する。飛散物の対地最 大水平速度 $U_{\mathrm{hmax}}=\sqrt{\left(U+u_{\mathrm{tr}}\right)^{2}+V^{2}}$ と対地最大実効速 度 $U_{\text {emax }}=\sqrt{\left(U+u_{t r}\right)^{2}+V^{2}+W^{2}}$ を, 条件を変えた計算例 について比較すると, 図 2 に示すように両者の差はほと んどない。ここで $U, V, W$ は渦に固定された座標系から 見た飛散物の速度である。これは, 対地最大実効速度が 発生する状態における水平速度は鉛直速度に比べて十分 大きいことを示している。ここでは飛散物の持つ運動量 およびエネルギーに対応している $U_{\mathrm{emax}}$ の大きさについ て検討を行う。また、図 1 に示すように物体の飛散は 3 次元的に分布するが, 以下では, 解析範囲内の全ての $x$ に おける対地最大実効速度を, 渦の進行方向前方から渦の

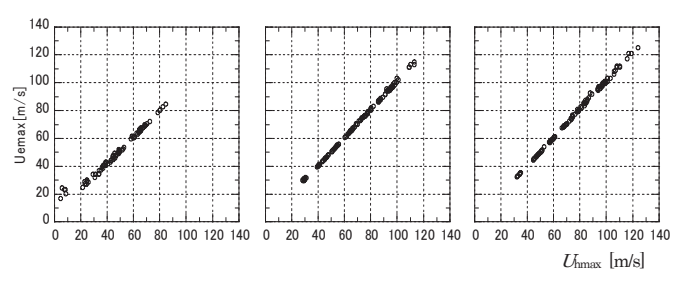

$C_{\mathrm{D}} A / m=0.007 \quad C_{\mathrm{D}} A / m=0.04 \quad C_{\mathrm{D}} A / m=0.07$

図 2 対地最大実効速度 $U_{\mathrm{emax}}$ と対地最大水平速度 $U_{\mathrm{hmax}}$ の関係

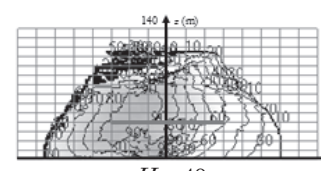

a. $H_{\mathrm{rl}}=40 \mathrm{~m}$

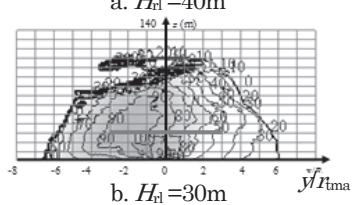

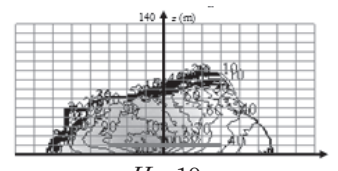

c. $H_{\mathrm{rl}}=10 \mathrm{~m}$



図 3 竜巻の進行方向からみた飛散物の対地最大実効速度 $U_{\mathrm{emax}}$ の分布. 放出高さ $H_{\mathrm{r}}$ による対地最大害効速度の違い. 図中の值 の単位は $\mathrm{m} / \mathrm{s}$, 放出位置を太線で表示.

方を見た $y-z$ 鉛直面に投影して検討を行う。

(1) 放出高さの影響

図 3 に示寸ように, 対地最大実効速度は渦の中心の左 で大きくなる。飛散物の存在する範囲は放出高さ $H_{\mathrm{rl}}$ に伴 側, 渦の回転と移動速度が加わり風速の大きくなる領域 で大きくなる。また，飛散物の対地最大実効速度の最大 值の発現位置も渦の左側, 最大接線風速半径の 3 倍以内 に見られ，放出高さと共に上空に広がる。対地最大実効 速度は放出高さが $40 \mathrm{~m}$ よりも低い方が大きいが，放出高 さ $20 \mathrm{~m}$ 以下ではほとんど変わらない。この傾向は空力パ ラメータ, 最大接線風速, 最大接線風速半径, 渦の移動 速度を変えた計算結果でも同様にみられる。これは, 竜 巻中の風速の最大值が水平，鉛直方向成分共に最大接線 風速半径の $0.2 \sim 0.4$ 倍程度の高さで生じているため, 高 さ40m よりも低いところで放出されると, 飛散物の落下 速度が小さい間に大きな相対風速を受けることになり， $40 \mathrm{~m}$ よりも高いところで放出された場合よりも高風速域 で滞留時間が長くなり, その分長い間加速されるためと 考えられる。

(2) 空力パラメータの影響

空力パラメータ $C_{\mathrm{D}} A / m$ の值は物体の飛び易さを示し 図 4 に示すように空力パラメータの值が大きくなるほど 対地最大実効速度は大きくなり，その飛散範囲も大きく なる。各高さにおける対地最大実効速度の分布をみると, 


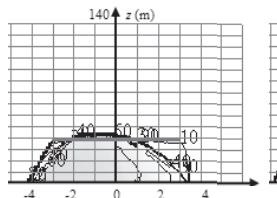
$C_{\mathrm{D}} \mathrm{A} / \mathrm{m}=0.007$

図4 竜巻の進行方向からみた飛散物の対地最大実効速度 $U_{\mathrm{emax}}$ の分布

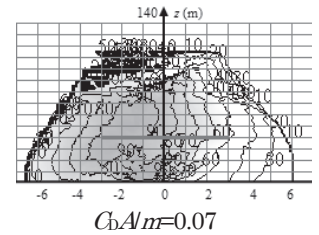

$C_{\mathrm{D}} A / m=0.07$

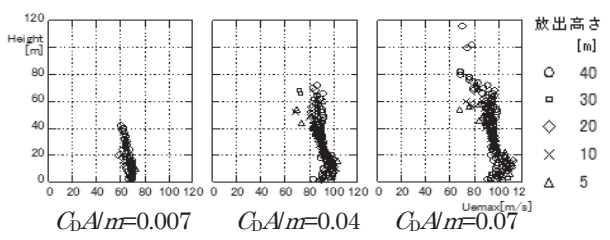

図 5 刘地最大実効速度 $U_{\mathrm{emax}}$ の高さ方向の変化

空力パラメータ $C_{\mathrm{D}} A / m$ による変化, 図中の值の単位は $\mathrm{m} / \mathrm{s}$, 放出位置は太線で表示, $H_{\mathrm{rl}}=40 \mathrm{~m}, u_{\mathrm{tmax}}=80 \mathrm{~m} / \mathrm{s}, r_{\mathrm{tmax}}=30 \mathrm{~m}, u_{\mathrm{tr}}=35 \mathrm{~m} / \mathrm{s}$

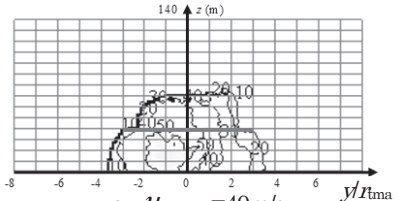

a. $u_{\text {tmax }}=40 \mathrm{~m} / \mathrm{s}$

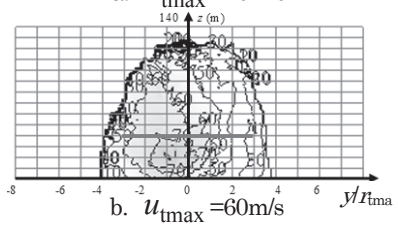

図6 竜巻の進行方向からみた飛散物の 対地最大実効速度 $U_{\mathrm{emax}}$ の分布

最大接線風速 $u_{\mathrm{tmax}}$ による変化, $H_{\mathrm{rl}}=40 \mathrm{~m}$, $C A / m=0.07 \mathrm{~m}^{2} / \mathrm{kg}, \quad r_{\text {tmax }}=60 \mathrm{~m}, u_{\mathrm{tr}}=15 \mathrm{~m} / \mathrm{s}$ 図中の值の単位は $\mathrm{m} / \mathrm{s}$, 放出位置は太線で表示

図 5 に示すように，空力パラメータの值が小さい場合 には各高さにおける最大值の発現は地面近くにみられ るが, 空力パラメータの值が大きくなるにつれて, 上 空に広がっていく様子が見られる。

（3）最大接線風速の影響

物体が受ける空気力は風速の 2 乘に比例して大きくな るので, 図6 亿示寸ように最大接線風速 $u_{\operatorname{tmax}}$ が大きくな るほど対地最大害効速度は大きくなる。

\section{（4）渦の移動速度の影響}

ここで示した解析結果においては, 渦の移動速度 $u_{\mathrm{tr}}$ は 物体を放出する際の相対風速淿影響を及ぼす。すなわち， 物体が放出される位置において, 渦と共に移動する座標 系から見た風速に移動速度を加えた相対風速を, 物体は 放出時に受けるとして計算している。飛散物の対地最大 実効速度は渦の移動速度とともに大きくなる。

（5）最大接線風速半径の影響

対地最大実恔速度は最大接線風速半径が大きくなるほ ど大きくなる傾向が見られる。

（6）最大接線風速に対寸る飛散物の最大速度

飛散物の最大速度が竜巻の最大接線風速 (時間平均値) の何倍になるかは興味のあるところである。今回示した 解析例において, 最大接楾風速 $u_{\text {tmax }}$ に対寸る飛散物の対 地最大実効速度 $U_{\mathrm{emax}}$ と渦の移動速度 $u_{\mathrm{tr}}$ の差である $U_{\mathrm{emax}}-u_{\mathrm{tr}}$ の倍率 $\left(U_{\mathrm{emax}}-u_{\mathrm{tr}}\right) / u_{\mathrm{t} \text { max }}$ をここでは飛散物

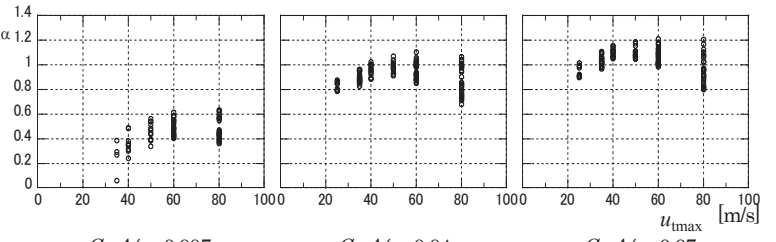

$C_{\mathrm{D}} A / m=0.007$

$C_{\mathrm{D}} A / m=0.07$
図 7 最大接線風速 $u_{\mathrm{tmax}}$ による増速率 $\alpha$ の変化

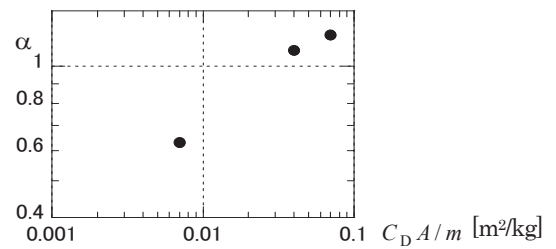

図 8 増速率の最大值 $\alpha_{\max }$ と空力パラメータ $C_{\mathrm{D}} A / m$ の関係

の増速率 $\alpha$ 之呼び, この増速率 $\alpha$ と最大接線風速 $u_{\operatorname{tmax}}$ との関係を求めると, 図7 亿示寸ように最大接線風速が 大きくなるほど，また，空力パラメータ $C_{\mathrm{D}} A / m$ が大き くなるほど, 増速率 $\alpha$ は大きくなる。ただし，最大接線 風速がある程度以上大きくなると，増速率 $\alpha$ の最大値は 一定となる傾向があり, $C_{\mathrm{D}} A / m=0.007 \mathrm{~m}^{2} / \mathrm{kg}$ の場合に は最大接線風速が $60 \mathrm{~m} / \mathrm{s}$ 以上で, $C_{\mathrm{D}} A / \mathrm{m}=0.04 \mathrm{~m}^{2} / \mathrm{kg}$ の 場合には最大接線風速が $40 \mathrm{~m} / \mathrm{s}$ 以上で, $C_{\mathrm{D}} A / m=$ $0.07 \mathrm{~m}^{2} / \mathrm{kg}$ の場合には最大接線風速が $40 \mathrm{~m} / \mathrm{s}$ 以上で，それ ぞれ増速率 $\alpha$ の最大值 $\alpha_{\text {max }}$ は0.6，1.1，1.2 となりその 関係は図 8 のようになる。竜巻中の瞬間風速の最大値は 最大接線風速 (時間平均値) の $1.5 \sim 1.7$ 倍程度となるこ とが計算されている ${ }^{35)}$ ので, 飛散物は飛びやすいものほ ど速度は大きくなり，その最大值は最大接線風速（時間 平均値）と同程度以上，瞬間風速の最大值の $80 \sim 90 \%$ 程 度に達すると考えればよいことが判る。

最後に, 実際に飛散物が建物等に衝突する速度は, 突風と建物, および建物周囲の状況により変化するが, 飛散物が慣性により，その速度を維持し続けようとす ることを考慮して，建物がない突風単独の場合の解析 結果を用いることは安全側の評価になると考えられる。 もちろん，飛散物の進路上にある地物が障害物となっ て飛散物の衝突を妨げる効果がある場合には，その効 果を考慮してもよい。 
3. 飛散物による被害の評価

飛散物により建物が受ける被害の程度を知るためには, 建物が飛散物から受ける衝撃力と，その衝撃力に建物が どの程度耐えられるかを明らかにする必要がある。建物 が受ける衝撃力は，飛散物の衝突速度，位置，角度によ り変化し, 建物側の耐衝撃性能は衝突される部位の物性 に依存する。飛散物は，屋根や壁，空などの開口部を覆 うガラスなど建物の外皮を構成する外装材に衝突して被 害を生じさせるため, 外装材に加わる衝撃力と，それに よる破壊の程度を評価することが基本となる。これらの 評価は被衝突体を試験体とし，試験体に飛散物を想定し た加撃体を衝突させて破壞性状を観察し，決められた判 定基準に合格するかどうかを判断することにより行われ る。

外装材などの耐衝撃性能評価は, 衝撃試験とその結果 を用いた性能評価を行うプロセスに分けられる。衝撃試 験においては想定される衝撃力を加えるために, 衝突速 度, 位置, 角度を規定している。このとき, 安全性の評 価を行う観点からは危険側の衝突条件, 寸なわち, 最も 衝撃力が大きくなる条件で衝突させ, 試験体の而衝撃性 能が最も弱くなる条件で試験を行う必要がある。

衝撃試験において, 飛散物は現実の飛散物（図9）を 模擬した加撃体で代用される。例えば，米国の $\mathrm{ASCE}^{42)}$ や $\mathrm{ASTM}^{43,44)}$ に強風時の飛散物に対する而衝撃性能試験・

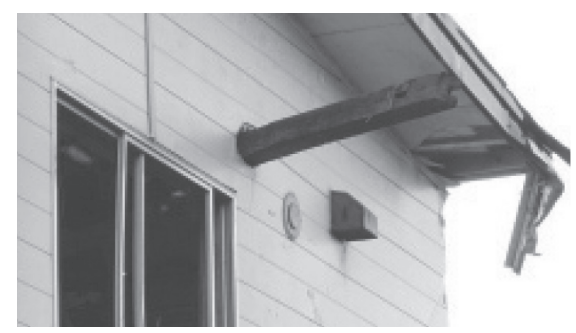

図9 壁に突き刺さった構造用柱 ${ }^{41)}$

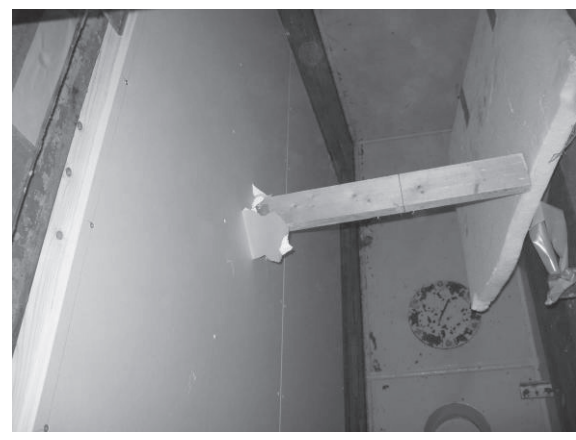

図10 外壁の衝撃試験の様子 ${ }^{50)}$

(加撃体である $2 \times 4$ の木片が内装材まで貫通している)
評価方法が示されており，そこでは加撃体として小さな 鋼球や $2 \times 4$ の木片が選ばれている。日本においてはこの ような試験・評価方法について独自のものが整備されて いないが, ASCEやASTMや, それらに倣って作られたISO 16932 25 などを採用することができる。なお，日本におけ る飛散物被害を考慮して, 丸山ら ${ }^{46)}$ は空ガラスの而衝撃 性能評価用の衝撃試験に用いる加撃体を, 瓦の飛散によ る被害を含めた形で提案している。加撃体を衝突させる 試験体には，飛散物が衝突する部位から実際の部材を切 り出して用いるのが基本となる（図10）。飛散物がもつ衝 撃力は衝突時に物体が持つ運動量や運動エネルギーで評 価されるが，衝撃試験においては試験体が実際に取り付 けられる位置, 建物の重要度, 建物が建つ地域によって, 加撃体の種類や衝突速度を選択寸ることにより, 衝撃力 を調整することになる。すなわち, 試験体が取り付けら れる位置については地面からの高さが低いほど，建物の 重要度が高いほど, 建物が建つ地域の強風の発生頻度が 大きいほど，衝撃力の大きな加撃体を選ぶことになる。

衝突位置, 角度については, 試験体の而衝撃性能が最 も弱い位置を含むように, 複数の試験体に, 各々数か所 加撃することになっており，ISO 16932では，図11に示す 位置に, 試験体の表面の垂直方向から $\pm 5^{\circ}$ 以内の角度で加 撃することとなっている。

これらの試験による合否判定は，上記のように飛散物 を模擬した加撃体を試験体の指定された部位に指定され た速度で衝突させたときに，規定以上の大きさのひびや 開口が生じるから゙うかで判断される。これは飛散物が建 物内部に侵入して人や設備に被害を生じさせない, 衝突 後の継続的な風圧にも耐え, 被害の拡大を防ぐために大 きな開口が開かないことを保証することを目的として決 められている。なお, ASTM, ASCEおよびISO 16932では,

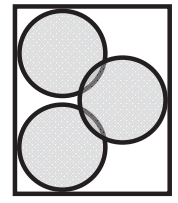

逆くの字

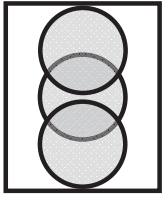

中央

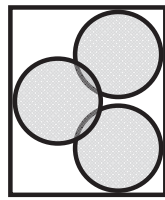

くの字 a. 加撃体として鋼球を用いる場合

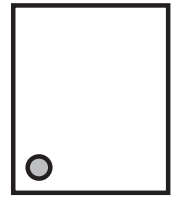

左下

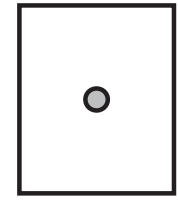

中央

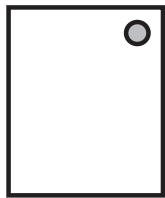

右上 b. 加撃体として $2 \times 4$ 木片を用いる場合

図 11 試験体への加撃位置（丸で囲われた範囲） 
加撃試験に続いて正負の圧力を繰り返し載荷する。これ は，台風やハリケーンなどのように強風が長時間持続す る場合を想定した試験であり, 竜巻などの突風時の衝撃 を想定したものではない。上述の耐衝撃性能評価方法に 関しての解説は文献47,48,49,50）を参照されたい。竜巻な どによって発生する飛散物による非常に大きな衝撃力に 対しても, その機能が損なわれないように防御すべき構 造物がある。日本における原子力施設に対する竜巻の影 響評価基準の例としては文献37）が挙げられ，想定する 竜巻の強さや飛散物の種類, 衝突速度などを規定してい る。

\section{4.おわりに}

突風による飛散物が構造物に及ぼす影響について、飛 散物の飛翔性状を左右する突風の気流性状, 飛散条件、 衝突による衝撃力の大きさ, 衝突によって生じる破壊の 程度と而衝撃性能の評価方法について, これまでに得ら れている学術的見地をもとに概観した。

\section{参考文献}

1) 奥田泰雄, 深井敦夫, 槌本敬大, 壁谷澤寿一, 喜々津仁密, 石井儀光, 中川貴文, 荒木康弘, 永井 渉: 2012 年 5 月 6 日つくば市で発生した竜巻による建築物の被害, 第 22 回風 工学シンポジウム論文集, pp.97-102, 2012.

2) J.A.B. Wills, B.E. Lee, T.A. Wyatt, "A model of wind-borne debris damage", J. Wind Eng. Ind. Aerodyn. 90, pp. 555-565, 2002.

3) 岡田, 強風による屋根瓦の飛散に関する風洞実験, 日本風 工学会誌日本風工学会誌, 35, 1-15, 1988.

4) 立川正夫, 福山雅弘,「平板の空力特性と飛散の性状につい て」, 第6 回風工学シンポジウム論文集, pp.231-238, 1980.

5) M. Tachikawa, "Trajectories of flat plates in uniform flow with application to wind-generated missiles", Journal of Wind Engineering and Industrial Aerodynamics, Vol.14, pp.443-453, 1983.

6) 立川正夫，「飛散物の拡散範囲の推定方法 台風時の飛散物 の軌跡と速度に関する研究 その 5 」, 日本建築学論文報告 集, pp.23-31, 1986.5 .

7) K. Wang, and C. W. Letchford, "Flying debris behavior", 11th International Conference on Wind Engineering, Lubbock, Texas Proceedings 2, 1663-1670, 2003.

8) J.D. Holmes, E.C. English, C. Letchford, "Aerodynamic forces and moments on cubes and flat plates, with applications to wind-borne debris", Summary Papers of the 5th International Colloquium on Bluff Body Aerodynamics and Applications, 103-106, 2004.

9) J. D. Holmes, C. W. Letchford, Ning Lin, "Investigations of plate-type windborne debries-Part II Computed trajectories",
Journal of Wind Engineering and Industrial Aerodynamics, 94, 21-39, 2006.

10) M. Noda and F. Nagao, "Simulation of $6 \mathrm{DOF}$ motion of $3 \mathrm{D}$ flying debris", Proceedings of 5th International Symposium on Computational Wind Engineering, 2010.

11) J. D. Holmes, "Trajectories of spheres in strong winds with application to wind-borne debris", Journal of Wind Engineering and Industrial Aerodynamics, 92, 9-22, 2004.

12) E. C. English, J. D. Holmes, "Non-dimensional solutions for trajectories of wind-driven compact objects", Proceedings of The Fourth European and African Conference on Wind Engineering, 2005.

13) N. Lin, J.D. Holmes, C.W. Letchford, "Trajectory of windborne debris and applications to impact testing", J. Structural Eng. ASCE, 133(2), 274-282, 2007.

14) P.J. Richards, N. Williams, B. Laing, M. McCarty, M. Pond, , "Numerical calculation of the 3-dimensional motion of wind-borne debris", J. Wind Eng. and Ind. Aerody., 96, 2188-2202, 2008.

15) 森本康幸, 前田潤滋, 「球状落下物の飛散距離に及ぼす強風 時風速変動の影響」, 日本建築学会大会学術講演梗概集, B-1, pp.171-172, 2006.

16）喜々津仁密, パーサ サーカー，「トルネード発生装置を活 用した建築物の飛散物衝撃リスク評価に関する一考察」, 第 58 回理論応用力学講演会講演論文集, NCTAM2009, pp.371-372, 2009.

17) 山下賢介, 佐々 浩司, 「竜巻に伴う飛散物の挙動」, 気象学 会大会, C253,(2007)

18）伊藤博泰，佐々浩司，宮城弘守，鈴木 修，「海上竜巻によ る水しぶきの模擬実験」, 日本風工学会誌 Vol.36, pp.193-194, (2011)

19）宮城弘守, 鈴木修, 佐々浩司, つくば市竜巻の漏斗雲画像 を用いた風速の推定, 風工学会誌, vol.38 No.2 (No.135),pp.141-142, 2013.

20) 野田 稔, 長尾 文明: 「2007年 8 月に徳島市で発生した竜巻 における風速推定」, 第 20 回風工学シンポジウム論文集, pp.169-174, 2008.

21) 平成 24 年 5 月 6 日に北関東で発生した竜巻の発生メカニズ ムと被害実態の総合調查,平成 24 年度文部科学省科学研究 費補助金 (特別研究推進費) 研究成果報告書, 研究代表者 前田潤滋，2013.2.

22) Masato Katafuchi, Yoshiaki Itoh and Tetsuro Tamura, LES analysis for behavior of a flying plate with rotation in turbulent flow 10ACWE (TENTH AMERICAS CONFERENCE ON WIND ENGINEERING), May31-June4, Baton Rouge, Louisiana, USA, (2005)

23) Bruce Kakimpa, David M. Hargreaves b, John S. Owen, "A Numerical Investigation of the Influence of Launch Conditions on Windborne Debris Flight", Proceedings of ICWE 13, USB, 8pages, (2011.8)

24）田村哲郎, 曹 曙陽, 柳 貴之, 奥田泰雄, 岡田 恒,「高層建物 
密集域での flying debris に関する LES 解析」, 日本風工学 会誌, 第95 号,pp.35-36, (2003)

25) Himoto K, Maruyama T, Tanaka T. A Study on The Brand Spotting in Urban Fires -LES Analysis on The Scattering of Square Disks in A Turbulent Boundary Layer-, Proc., 10th INTERFLAM, Vol.2, pp.1039-1050,(2004)

26) 森本康幸, 前田潤滋, 「球状落下物の飛散距離に及ぼす強風 時風速変動の影響」, 日本建築学会大会学術講演梗概集, B-1, pp.171-172, (2006)

27) 野田 稔, 長尾文明, 政井一仁, 六自由度飛行軌道解析に よる平板状飛散物の飛行性状の検討, 構造工学論文集, Vol.58A, pp.542-551, 2012.

28）岡崎純也・丸山 敬 : 瓦と正方形平板の飛散性状のシミュレ ーション, 第 22 回風工学シンポジウム論文集, 2012.12 , pp.377-382.

29) E. Simiu, M. Cordes, "Tornado-borne missile speeds", NBSIR 76-1050, National Bureau of Standards, Washington, DC. , (1976)

30) Regulatory Guide 1.76, Revison1, "Design-basis tornado and tornado missiles for nuclear power plants," U.S. Nuclear Regulatory Commission, 2007.

31）河井宏允，「竜巻時の被害分布と飛散物体の方向について」, 日本建築学会大会学術講演梗概集，97-98，(2007)

32）竜巻飛来物飛散特性に対する物体初期位置の影響評価 江 口 譲, 杉本 聡一郎, 服部 康男, 平口 博丸, 日本風工学会 年次研究発表会・梗概集, Vol. 2015 (2015), pp.151-152.

33) Fujita, T. T., "Workbook of tornadoes and high winds for engineering applications", U. Chicago, (1978).

34) D. C. Lewellen, Baiyun Gong, W. S. Lewellen, "Effects of Finescale Debris on Near-Surface Tornado Dynamics", Journal of the Atmospheric Sciences ， Vol. 65, pp.3247-3262, (2008)

35) T. Maruyama, "Simulation of flying debris using a numerically generated tornado-like vortex", Journal of Wind Engineering and Industrial Aerodynamics, 99(4), pp.249-256, (2011)

36) 設計基準竜巻のパラメータ, 平成 $21 \sim 22$ 年度原子力安全基 盤調査研究 (平成 22 年度) 竜巻に関する原子力施設への影 響に関する調查研究, 東京工芸大学, pp.175-180, 2011.

37)「原子力発電所の竜巻影響評価ガイド」, 原子力規制委員会, 平成 25 年 6 月, 2013

38) Peter J. Vickery, Jason X. Lin, Lawrence A. Twisdale Jr.,
"Analysis of hurricane pressure cycling following missile impact for residential structures", Journal of Wind Engineering and Industrial Aerodynamics, Vol.91, pp.1703-1730, (2003)

39) J. D. Holmes, C. J. Baker, Y. Tamura, "Short note Tachikawa number: A proposal", Journal of Wind Engineering and Industrial Aerodynamics, Vol.94, pp.41-47, (2006)

40) 丸山 敬・河井宏允・奥田泰雄・中村 修: 数值計算による 竜巻中の飛散物の速度推定, 第 23 回風工学シンポジウム論 文集, 2014.12,pp.487-492.

41) 日本建築学会 : 建築物外装材の而風設計と而風性能評価に 関するシンポジウム, 2008.11 .

42) ASCE 7-05, "Minimum Design Loads for Buildings and Other Structures", ASCE (American Society of Civil Engineers) Standard.

43) ASTM E1886-04, "Standard Test Method for Performance of Exterior Windows, Curtain Walls, Doors, and Impact Protective Systems Impacted by Missile(s) and Exposed to Cyclic Pressure Differentials", ASTM (American Society for Testing and Materials) Standard.

44) ASTM E1996-04, "Standard Specification for Performance of Exterior Windows, Curtain Walls, Doors, and Impact Protective Systems Impacted by Windborne Debris in Hurricanes", ASTM (American Society for Testing and Materials) Standard.

45) ISO 16932, "Glass in building -Destructive-windstormresistant security glazing - Test and classification”, ISO

46) 丸山敬 - 河井宏允 - 西村宏昭 - 花谷真由子 : 種々の加撃体 を用いた合わせガラスの耐衝撃試験と標準加撃体の提案, 日本風工学会論文集, Vol. 39No. 1 [No. 138], pp. 1-12, 2014.1.

47) 丸山 敬・河井宏允・西村宏昭 - 加茂正人 : 外装材耐衝撃性 能試験用エアーキャノン, 日本風工学会誌, Vol.34, No.2 (No.119), 2009.4, pp.31-38.

48) 丸山 敬: 飛散物に対する外装材の而衝撃性能の評価方法に ついて, 日本風工学会誌, Vol.35, No.1 (No.122), 2010.1, pp.33-40.

49) 西村宏昭:飛散物の発生防止と防御、日本風工学会誌, Vol.35, No.1 (No.122), 2010.1, pp.41-46

50)「平成23年度建築基準整備促進事業 風圧力、而風設計等 に関する基準の合理化に資する検討報告書、平成24年3月 